\title{
ラットのレバー押しによるシドマン 回避行動におよぼす鉛の影響
}

\author{
Effects of Lead on Sidman Avoidance Behavior by Lever Pressing in Rats
}

東海大学医学部衛生学教室

\author{
重 田 定 義·三澤 哲 夫・相川浩 幸 \\ 東海大学医学部法医学教室
}

\author{
平瀬文子・永田正博
}

Sadayoshi Shigeta, Tetsuo Misawa and Hiroyuki Aikawa

Department of Environmental Medicine and Occupational Health, School of Medicine, Tokai University, Isehara

Fumiko Hirase and Masahiro Nagata

Department of Legal Medicine, School of Medicine, Tokai University, Isehara

Effects of asymptomatic lead exposure on Sidman avoidance behavior in rats were studied. The animals were administered asymptomatic doses of lead acetate until 60 days of age through maternal milk while suckling and drinking water after weaning. From 61 days of age, learning patterns for lever pressing and shock avoidance of animals were investigated for one hour every other day for a total of 10 sessions.

1) The mean concentration of lead in rats administered $2 \mathrm{mg} / \mathrm{ml}$ lead was $34.8 \mu \mathrm{g} / 100 \mathrm{~g}$ in the blood, and $99.3 \mu \mathrm{g} / 100 \mathrm{~g}$ in the brain at 60 days of age, and no significant differences were seen in shock avoidance learning when compared with the control group.

2) The mean lead level of lead in rats administered $5 \mathrm{mg} / \mathrm{ml}$ lead was $73.2 \mu \mathrm{g} / 100 \mathrm{~g}$ in the blood, $222.4 \mu \mathrm{g} / 100 \mathrm{~g}$ in the brain at 60 days of age, and the acquisition of shock avoidance patterns was significantly delayed in the first five sessions of the learning period when compared with the control group.

3) The acquisition of shock avoidance patterens in the $5 \mathrm{mg} / \mathrm{ml}$ lead group was similar to that of the control group in the second half of the training sessions. These results indicated that reinforcement stimulus by electric shock used on a Sidman avoidance schedule was a very strong reinforcement stimulus of those used in the operant behavior experiments.

\section{緒}

言

明らかな臨床症状を呈しない程度の, 少量の鉛曝露に よる小児の鉛中毒として, 諸外国では知能障害や行動異 常の有無が問題とされている( ${ }^{4)}$ 。一方, 乙の問題につ いて動物のモデルを用い, 動物の学習行動から究明しよ うとする研究がおこり,すでにいくつかの業績が発表さ れている5 14)。

しかし，乙れらの報告をみると，毒性評価の指標に用
いられる学習方法や，鉛の投与方法，投与時期，投与量 などがそれぞれ異なり，その結果鉛の学習行動におよぼ す影響は必ずしあ一定していない。

著者らは,レバーを押すごとにペレットの報酬が与え られるといういわゆる正の強化スケジュールで訓練する と，哺乳期に母乳を介して少量の鉛を投与したラットで は学習の遅延が認められるが，離乳後から鉛を投与した ラットにはかかる結果は得られないととをすでに明らか にした ${ }^{15)}$ 。 
今回は，レバーを押すととによって電撃ショックを回 避するという, 前回とは逆の負の強化スケジュールを用 い，学習過程におけるラットのショック回避習得の遅延 の有無によって，中枢神経に対する鉛の毒性評価をおこ ない，あわせて学習スケジュールが学習行動パターンに およぼす影響について検討した。

\section{実験材料および実験方法}

実験動物：個体差ならびに母親の哺育差を極力少なく する目的で, ウイスター系の10週秢の䊒ラットと15週齢 の雄ラットを当教室で交配し, 妊娠したラット 9 匹から 生まれた仔数を整理して 1 腹当たり 9 匹とし, 出生後 2 日目から交叉哺育をおてなった。学習訓練には雄を使用 するが，雄仔は合計33匹であったので，交叉哺育により 自腹の雄任数は 1 腹当たり $1 \sim 2$ 匹となった。

鉛投与および飼育条件：交叉哺育開始と同時に母ラッ 卜は無作為に 3 匹ずつ 3 群にわけられ，それぞれ $2 \mathrm{mg} /$ $\mathrm{m} l, 5 \mathrm{mg} / \mathrm{m} l$ の酶酸鉛水溶液および対照として $5 \mathrm{mg} / \mathrm{ml}$ の酢酸ソーダ水溶液を飲水として自由に摂取せしめた。 哺乳期間中は，仔はその母親とともに同一ケージ内で飼 育した。離乳後, すなわち21日齢以降は, 雄仔は 1 匹ず つ個別のケージで飼育し, 哺乳時にひき続して母親に与 えたと同濃度の酷酸鉛水溶液, または酥酸りーダ水溶液 を60日齢まで自由に摂取せしめた。なお，飼育は年間を 通じて室温 $23 \pm 2{ }^{\circ} \mathrm{C}$, 気湿 $55 \pm 10 \%$ の飼育室でおてない, 実験期間の間は学習訓練の時間を除いて餌 (CE-2, 日本 クレア）は自由に与えた。

学習の方法と手順：学習訓練には，制御部，記録部な らびにスキナー箱からなる条件回避反応測定装置（群大 式)おおよ゙ BRS/LVE 社製のコンピュータ制御による 制御・記録部ならびにスキナー箱からなるオペラント行 動測定装置を用いた。なお，予備実験において，二つの 測定装置の間における学習行動量に差がないととを確認 した。学習スケジュールには，もっとも基本的な条件回 避スケジュールの 1 つであるシドマン回避スケジュール を採用し，刺激一刺激間隔は 5 秒，反応一刺激間隔は 30 秒行設定した。このスケジュールでは，ラットはスキナ 一箱内でレバーを押さなければ 5 秒ごとに床のグリッド から瞬間的に電撃をうけ，レバーを押せば次の電撃まで 30 秒間はショックを回避できる。学習訓練は61日齢から 開始し, 各ラットとむ 1 日 1 時間ずつ隔日 10 回実施し た。学習行動の指標には, 反応数すなわちレバー押し回 数ならびに被ショック数を用い，60分間のオペラント学 習訓練のなかでレバー押しの安定する後半30分間の值を
とり，10分当たりの反応数あるいは被ショック数として あらわした。なお，詶練は飼育室と同じ温熱環境下にお いて, 午前 9 時加ら午後 2 時の間におこない, 各群とも に同一ラットが同一時間帯に訓練をうけるよう配慮し た。

血中ならびに脳中鉛量の分析：哺乳および飲水によっ て体内に摂取された鉛のうち，血中および脳中に移行し た鉛量之学習行動との関係を知る目的で, 学習訓練に使 用する雄仔之同一の母ラットによって哺育され，その後 は飲水によって鉛を摄取した同腹の雌仔を，30日齢と60 日齢に達した時点において各群 5 匹ずつ放血屠殺し, 血 液および脳を湿式灰化ののち DDTC-MIBK によって抽 出し, 原子吸光法 (日立原子吸光光度計170-50) によっ て分析定量した。

発育状態：体重増加，開眼，発毛，歩行開始などの発 育成長に関する指標について, 交叉哺育值後から学習訓 練開始まで，継続して観察記録した。

$$
\text { 結果 }
$$

開眼, 発毛および歩行開始の時期は，鉛投与群と対照 群との間に差はみられなかったが，体重は Fig. 1 の如く に $5 \mathrm{mg} / \mathrm{m} l$ 鉛投与群においてその増加が対照群よりも 有意に少ない。しかし, $2 \mathrm{mg} / \mathrm{m} l$ 鉛投与群と対照群との

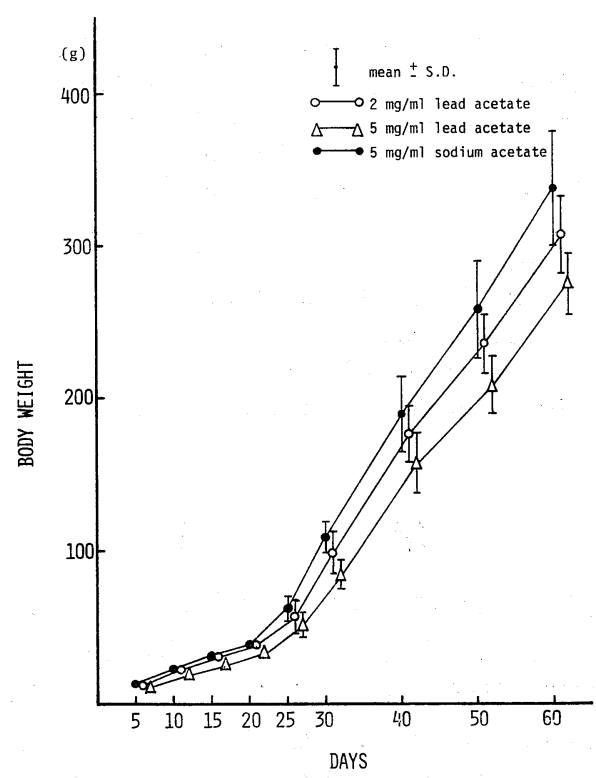

Fig. 1 Body weight increases in $2 \mathrm{mg} / \mathrm{m} l \mathrm{~Pb}$ group, $5 \mathrm{mg} / \mathrm{m} l \mathrm{~Pb}$ group and control group 
重田・三澤・相川・平瀬・永田 : ラットのレバー押しによるシドマン回避行動に およぼす鉛の影響

Table 1 Lead concentrations in the blood and in the brain of rats at age of 30 and 60 days (mean \pm S.D.)

\begin{tabular}{l|r|r|r|r}
\hline & & \multicolumn{3}{|c}{ Administration conditions (mg/ml) } \\
\cline { 3 - 5 } & Age & \multicolumn{2}{|c}{ Lead acetate } & Sodium acetate \\
\cline { 3 - 4 } & & 2.0 & 5.0 & 5.0 \\
\hline Lead concentration in the blood & 30 days & $114.6 \pm 12.6$ & $307.6 \pm 34.4$ & $<4$ \\
$(\mu \mathrm{g} / 100 \mathrm{~g})$ & 60 days & $34.8 \pm 11.3$ & $73.2 \pm 26.5$ & $<4$ \\
Lead concentration in the brain & 30 days & $84.4 \pm 15.8$ & $99.3 \pm 10.7$ & $<4$ \\
$(\mu \mathrm{g} / 100 \mathrm{~g})$ & 60 days & $171.8 \pm 7.9$ & $222.4 \pm 80.9$ & $<4$ \\
Number of rats & 30 days & 5 & 5 & 5 \\
& 60 days & 5 & 5 & 5
\end{tabular}

間における体重増加には有意差はみられなかった。

血中鉛量および脳中鉛量は Table 1 の通りである。血 中鉛量は，30日柃と60日秢にとすに投与濃度に比例した 鉛量の増加がみられた。しかし，60日齢における鉛量は $2 \mathrm{mg} / \mathrm{ml}$ 鉛投与群では平均 $34.8 \mu \mathrm{g} / 100 \mathrm{~g}, 5 \mathrm{mg} / \mathrm{ml}$ 鉛 投与群では平均 $73.2 \mu \mathrm{g} / 100 \mathrm{~g}$ といずれも 30 日龄の血中 濃度と比較して約 $1 / 4$ 亿減少している。一方, 脳中鉛量に

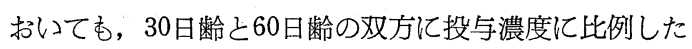
鉛量の増加がみられたが，血中鉛量とは異なり，60日齢 における脳中鉛量は $2 \mathrm{mg} / \mathrm{m} l$ 鉛投与群では, 平均 99.3 $\mu \mathrm{g} / 100 \mathrm{~g}, 5 \mathrm{mg} / \mathrm{ml}$ 鉛投与群では平均 $222.4 \mu \mathrm{g} / 100 \mathrm{~g}$ 之, むしろ30日龄の鉛量よりやや多い傾向がみられた。

学習訓練の結果は, Table 2, 3 および Fig. 2, 3 亿

Table 2 Response counts per $10 \mathrm{~min}$ in 2 , $5 \mathrm{mg} / \mathrm{m} l \mathrm{~Pb}$ groups and control group during 10 sessions by a Sidman avoidance test

$($ mean $\pm \mathrm{SE})$

\begin{tabular}{c|c|c|c}
\hline \multirow{2}{*}{ Sessions } & \multicolumn{3}{|c|}{ Administration conditions $(\mathrm{mg} / \mathrm{m} l)$} \\
\cline { 2 - 4 } & \multicolumn{2}{|c|}{ Lead acetate } & $\begin{array}{c}\text { Sodium } \\
\text { acetate }\end{array}$ \\
\cline { 2 - 4 } & 2.0 & 5.0 & 5.0 \\
\hline 1 & $38.5 \pm 4.6$ & $34.1 \pm 4.1$ & $32.4 \pm 4.1$ \\
2 & $47.1 \pm 5.7$ & $35.1 \pm 4.0$ & $39.3 \pm 3.1$ \\
3 & $44.1 \pm 4.4$ & $34.5 \pm 3.8$ & $36.9 \pm 2.0$ \\
4 & $43.2 \pm 4.2$ & $36.8 \pm 3.5$ & $39.4 \pm 2.5$ \\
5 & $46.3 \pm 2.9$ & $38.8 \pm 2.5$ & $38.2 \pm 2.3$ \\
6 & $45.9 \pm 3.3$ & $40.3 \pm 2.3$ & $34.7 \pm 2.5$ \\
7 & $43.6 \pm 2.5$ & $41.4 \pm 2.0$ & $40.5 \pm 1.9$ \\
8 & $46.5 \pm 2.7$ & $42.7 \pm 2.2$ & $35.4 \pm 2.0$ \\
9 & $45.6 \pm 2.3$ & $40.5 \pm 2.4$ & $43.5 \pm 2.5$ \\
10 & $46.5 \pm 2.1$ & $41.6 \pm 2.4$ & $44.2 \pm 2.4$ \\
\hline
\end{tabular}

示す。レバー押しによる反応数は, Table 2 をみる限り においては対照群も両鉛投与群も学習訓練初日があっと あ少ないという以外には特に一定の傾向はみられ難い。 しかし，各群について各訓練日の反応数を，訓練初日の 反応数を基準にした反応増加率であらわすと，Fig. 2 の ように対照群ならびに $2 \mathrm{mg} / \mathrm{m} l$ 鉛投与群は訓練の 2 回 目に急激に $20 \%$ 反応が増加し，その後はこの $20 \%$ 増加 ライン前後で推移するが, 一方, $5 \mathrm{mg} / \mathrm{ml}$ 鉛投与群では 最初の 3 回は反応数が増加せず, その後徐々に増加して, 訓練の 6 回目にようやく $20 \%$ 増加ラインに到達するとと が示された。

被ショック数は, Table 3 の如く学習訓練初日では対 照群， $2,5 \mathrm{mg} / \mathrm{m} l$ 鉛投与群とあにほぼ同じであるが, その後の推移は各群によって異なっている。すなわち, 各群について各訓練日の被ショック数を, 訓練初日の被 ショック数を基準にした被ショック減少率であらわすと,

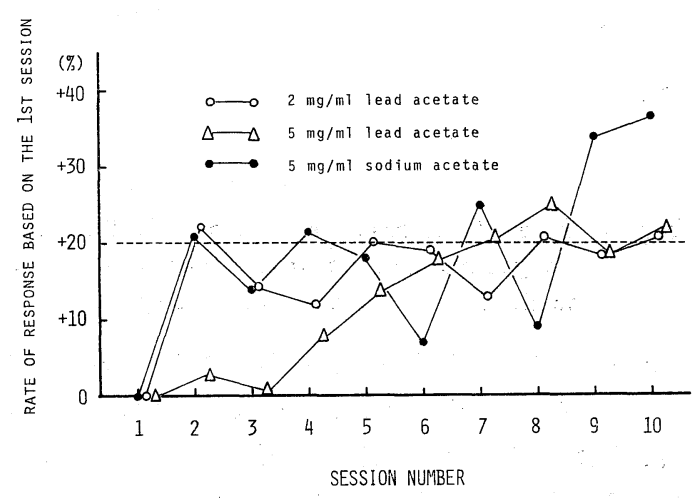

Fig. 2 Rate of increase for responses in 2, $5 \mathrm{mg} / \mathrm{m} l \mathrm{~Pb}$ groups and control group during 10 sessions by a Sidman avoidance test 
Table 3 Shock counts per $10 \mathrm{~min}$ in 2, $5 \mathrm{mg} / \mathrm{m} l \mathrm{~Pb}$ groups and control group during 10 sessions by a Sidman avoidance test

(mean $\pm \mathrm{SE}$ )

\begin{tabular}{c|c|c|c}
\hline \multirow{2}{*}{ Sessions } & \multicolumn{2}{|c|}{ Administration conditions $(\mathrm{mg} / \mathrm{ml})$} \\
\cline { 2 - 4 } & \multicolumn{2}{|c|}{ Lead acetate } & $\begin{array}{c}\text { Sodium } \\
\text { acetate }\end{array}$ \\
\cline { 2 - 4 } & 2.0 & 5.0 & 5.0 \\
\hline 1 & $39.0 \pm 6.3$ & $37.2 \pm 5.6$ & $36.7 \pm 5.7$ \\
2 & $29.8 \pm 6.0$ & $32.4 \pm 5.4^{1)}$ & $17.9 \pm 2.0$ \\
3 & $25.5 \pm 5.7$ & $30.3 \pm 5.5^{2}$ & $14.7 \pm 1.5$ \\
4 & $22.5 \pm 4.8$ & $25.0 \pm 4.4^{1)}$ & $15.3 \pm 2.0$ \\
5 & $10.8 \pm 1.2$ & $16.1 \pm 2.6$ & $13.6 \pm 2.1$ \\
6 & $11.8 \pm 1.2$ & $12.7 \pm 1.5$ & $17.4 \pm 2.2$ \\
7 & $10.4 \pm 1.0$ & $12.8 \pm 1.4$ & $10.3 \pm 1.2$ \\
8 & $10.0 \pm 1.0$ & $11.9 \pm 1.3$ & $13.6 \pm 1.3$ \\
9 & $8.8 \pm 1.3$ & $9.6 \pm 1.4$ & $10.2 \pm 1.1$ \\
10 & $8.1 \pm 0.9$ & $10.0 \pm 1.6$ & $10.2 \pm 1.7$ \\
\hline
\end{tabular}

1): Significant at $5 \%$ level, relative to control, in Student's t-test

2): Significant at $1 \%$ level, relative to control, in Student's t-test

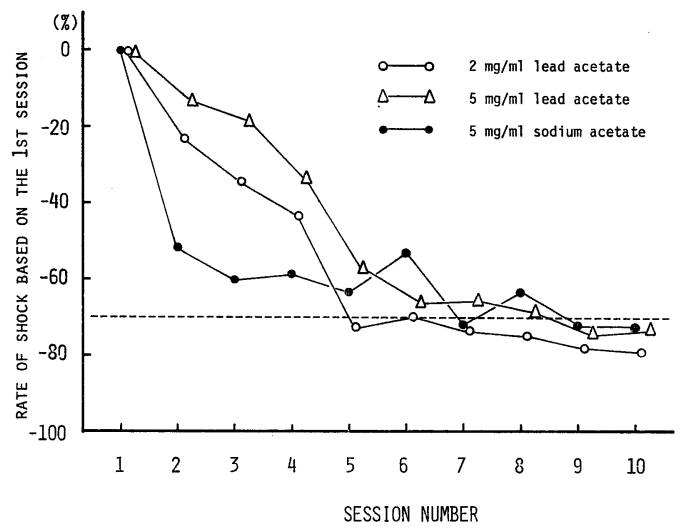

Fig. 3 Rate of decrease for shocks in $2,5 \mathrm{mg} / \mathrm{m} l$ $\mathrm{Pb}$ groups and control group during 10 sessions by a Sidman avoidance test

Fig. 3 のように対照群は訓練の 2 回目にはやくも $50 \%$ 減 少ラインに達し，その後は減少がゆるやかとなって 7 回 目からは70\%减少ライン前後で推移するが, $5 \mathrm{mg} / \mathrm{m} l$ 鉛 投与群は被ショック娍少率がきわめてゆるやかで，5回 目においてようやく $50 \%$ 減少ラインを下廻り， 8 回目で $70 \%$ 減少ライン近くに達する。また, $2 \mathrm{mg} / \mathrm{m} l$ 鉛投与群 は対照群と $5 \mathrm{mg} / \mathrm{m} l$ 鉛投与群の中間に 位置し, 訓練 4
回目で50\%減少ライン近くに達し，5 回目からは70\%減 少ライン前後で推移する。

平均被ショック数について，それぞれの群の間におけ る有意性の検定を訓練日ごとにおこなうと, Table 3 の 如く対照群之 $5 \mathrm{mg} / \mathrm{m} l$ 鉛投与群の間において訓練の 2 , 3,4 回の各回に有意差が認められたが, 対照群と $2 \mathrm{mg} /$ $\mathrm{m} l$ 鉛投与群との間，ならびに $2 つ の$ 鉛投与群の間には 有意差を認めなかった。

以上の 2 つのオペラント行動の指標を用いて分析した 結果をまとめると，シドマン回避スケジュールを用いた 学習訓練によって，対照ラットと比べて鉛投与ラットに は学習過程の前半の段階においてショック回避学習の習 得が遅延することが明らかになった。

$$
\text { 考察 }
$$

鉛とラットの学習行動との関係を究明する目的でこれ までの研究に用いられた学習実験法は, 大別して迷路法, 逃・回避箱法抢よびレバー押し法にわけられ，研究者に よっては各種の弁別反応をてれと組み合わせて用いてい る。すなわち, Snowdon (1) Hebb-Williams 迷路テスト によって, Brady ら ${ }^{9)}$ は黒白弁別迷路テストで鉛投与群 に対照群よりエラーが多いとし, Driscoll ら ${ }^{10)}$ は明暗弁 別迷路テストに抢いて, Overmann ${ }^{13)}$ はシャトル箱にお ける電撃回避テストで，また Winneke ら ${ }^{12)}$ は Lashley 型跳躍台における円の大小弁別学習にて，いずれあ鉛投 与群に学習の習得遅延か認められた之報告している。

レバー押しによるオペラント行動は, 逃・回避箱や走 路, 迷路による実験の如くに, 行動を大きく左右する運 動機能に影響されないという長所がある。との方法を用 いた実験では, Padich ら ${ }^{14)}$ は20回レバーを押すごとに 報酬が与えられる Fixed Ratio (FR)-20 の学習スケジ ュール, Shigeta ら ${ }^{15)}$ はR-10の学習スケジュールで 鉛投与群に学習の習得遅延が認められたととを報告して いる。しかし，一方には Hastings ら"1)のレバー押しに よる光弁別テストにおいて，また，Brown ら5)のT迷路 ならびにシャトル箱による弁別回避テストにおいて，鉛 による学習への影響はみられないとする報告むある。

著者らが今回の実験で用いたレバー押しによるシドマ ン回避スケジュールは，基本的な負のオペラント学習ス ケジュールの1つであり, あっとあ学習が容易であると されている(16)。乙の学習スケジュールによる訓練におい て, 学習過程の前半において反応数増加ならびに被ショ ック数減少の速度が対照群より遅く，鉛によってショッ ク回避の習得に遅延が生じたてとが示された。さらに, 
学習訓練が進むにしたがい, 鉛投与群む対照群と同様の ショック回避を示すようになるが，乙れは，電撃という 罰を強化刺激として用いる学習によるショック回避習得 は遅延とそすれ，鉛の投与によってあ対照群と同レベル まで達成されうるととを示すすのである。

すでに著者らはトルエン曝露のラットの中枢神経にお よぼす影響について, シドマン回避スケジュールを用い て成熟ラットに学習訓練をおこない，確立したレバー押 し行動基線がトルエン曝露で乱されるととから, トルエ ンの毒性を評価しうることを明らかにした ${ }^{18)}$ が，今回， 学習過程におけるショック回避習得が鉛によって遅延す るととが明らかになったてとによって，行動基線の乱れ による評価以外に, 学習過程における学習遅延の度合い による評価も有用であるととが示された。

また, Shigeta ら ${ }^{15)}$ やPadich ら ${ }^{14)}$ の報告では, 正の 強化刺激による学習の容易なスケジュールである FR ス ケジュールによる学習訓練で, 学習過程が進むにつれて 鉛投与ラットに学習が遅延するととを認めたが，てのよ うに，報酬を強化刺激としてあ罰を強化刺激としても， 鉛による影響が学習行動にあらわれたが、レバー押し行 動のパターンや, 学習過程にお打る学習遅延のパターン は, 正と負の強化刺激によって異なるととも明らかにな つた。

Pentschew ら ${ }^{17)}$ は，哺乳期に母乳を介して鉛を移行さ せることによって, 始めてラットに鉛による脳症を発生

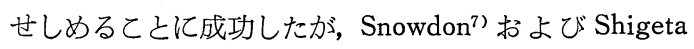
ら ${ }^{15)}$ は，鉛投与を哺乳中からおこなった場合と離乳以降 からおこなった場合とについて比較検討し哺乳期のうち に無症状量の鉛を投与したラットに学習の遅延あるいは エラーの多いととを確かめている。しかしながら, 今回 の著者らの実験に打いても, Snowdon $\left.{ }^{7}\right)$ Shigeta ら ${ }^{15)}$ の報告にみられる如く, 哺乳期における鉛の投与は, 外 見上何等の異常行動むみられず，また発育成長の指標の なかの開眼, 発毛, 歩行開始については対照群と差がみ られない程度のいわゆる無症状量であっても, 体重増加 には影響を与えることが示された。

学習の成績を投与鉛濃度からだけではなく，体内鉛量 との関連に扔いて検討した報告は少なく，脳中鉛ならび に血中鉛の分析は，著者らのほかは Hastings ら ${ }^{11)}$ のみ であり，血中鉛量の記載むわずかに Winneke ら ${ }^{12)}$ およ び Overmann ${ }^{13)}$ のみである。Hastings ら ${ }^{111} は 0.1 \%$ 酢 酸鉛を母乳を介して投与し，離乳後40日目の60日踰にお ける脳中鉛は $14 \mu \mathrm{g} / 100 \mathrm{~g}$ ，血中鉛は $9 \mu \mathrm{g} / 100 \mathrm{~g}$, Winneke ら ${ }^{12)}$ は哺乳中は母親に, 離乳後は直接 $745 \mathrm{mg} / \mathrm{kg}$
の酢酸鉛を投与し，190日齢で血中鉛量が $28.5 \mu \mathrm{g} / 100 \mathrm{~g}$, Overmann ${ }^{13}$ ) は哺乳期のみに $90 \mathrm{mg} / \mathrm{kg}$ の酢酸鉛を投与 し，35日秢に执いて血中鉛量が $56 \mu \mathrm{g} / 100 \mathrm{~g}$ であったと している。著者らは前回の実験においては哺乳期にのみ 母乳を介して鉛を投与し, $5 \mathrm{mg} / \mathrm{m} l$ 鉛投与群では 60 日齢 で脳中鉛量は $22 \mu \mathrm{g} / 100 \mathrm{~g}$ であったが，今回の実験では 離乳後むひき続き鉛を投与した結果，60日跉には $5 \mathrm{mg} /$ $\mathrm{m} l$ 鉛投与群で血中鉛量は $73 \mu \mathrm{g} / 100 \mathrm{~g}$ であったが, 脳

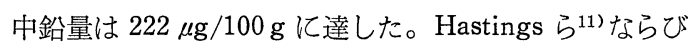
に Brown ら5)は, ラットの学習に対する鉛の影響は認め られなかったとしているが, ての理由は, Hastings らの 研究においては脳内の鉛量が極めて微量であったためで あり，またBrown らの研究に抢いては，鉛の投与が学 習実験の直前のわずか 3 ないし 4 回のみであったためと 考えられる。

$$
\text { 結論 }
$$

哺乳期には母乳を介して, その後60日歯まで飲水とし て鉛を投与したウイスター系ラットの中枢神経系におよ ぼす鉛の影響を，レバー押しによるシドマン回避行動に よって分析し，次の如き結果を得た。

1. $2 \mathrm{mg} / \mathrm{m} l$ 酶酸鉛投与群は, 60 日齢で血中鉛量は平 均 $34.8 \mu \mathrm{g} / 100 \mathrm{~g}$, 脳中鉛量は平均 $99.3 \mu \mathrm{g} / 100 \mathrm{~g}$ を示し, 学習成績はショック回避の習得がやや対照群に比し遅延 する傾向はうかがわれるが有意差は認められなかった。

2. $5 \mathrm{mg} / \mathrm{ml}$ 酢酸鉛投与群は, 60 日齢で血中鉛量は平 均 $73.2 \mu \mathrm{g} / 100 \mathrm{~g}$, 脳中鉛量は平均 $222.4 \mu \mathrm{g} / 100 \mathrm{~g}$ を示 し, 学習成績ではショック回避習得の遅延が対照群に比 し学習訓練の初回から 5 回までは有意に認められた。

$3.5 \mathrm{mg} / \mathrm{m} l$ 酷酸鉛投与群においても学習訓練の 5 回 目以降は対照群と同程度にショック回避が習得できたて とは，オペラント学習行動実験に用いられる強化刺激の なかで, 電撃による強化刺激が極めて強烈であるととを 示す。

\section{文献}

1) Byers, R. K. and Lord, E. E.: Late effects of lead poisoning on mental development, Amer. J. Dis. Child., 66, 471-494 (1943).

2) Perlstein, M. A. and Attala, R.: Neurologic sequelae of plumbism in children, Clin. Pediat., 5, 292-298 (1966).

3) Baloh, R., Sturm, R., Green, B. and Gleser, G.: Neuropsychological effects of chronic asympto- 
matic increased lead absorption, Arch. Neurol., 32, 326-330 (1975).

4) Hebel, J. R., Kinch, D. and Armstrong, E.: Mental capacity of children exposed to lead pollution, Brit. J. Prev. Soc. Med., 30, 170-174 (1976).

5) Brown, S., Dragann, N. and Vogel, W. H.: Effects of lead acetate on learning and memory in rats, Arch. Environ. Health, 22, 370-372 (1971).

6) Shapiro, M. M., Tritchler, J. M. and Ulm, R. A.: Lead contamination: Chronic and acute behavioral effects in the albino rat, Bull. Psychol. Soc. 2. 94-96 (1973).

7) Snowdon, C. T.: Learning deficits in lead-injected rats, Pharmac. Biochem. Behav., 1, 599-603 (1973).

8) Carson, T. L., Van Gelder, G. A., Karas, G. C. and Buck, W. B.: Slowed learning in lambs prenatally exposed to lead, Arch. Environ. Health., 29, 154-156 (1974).

9) Brady, K., Herrera, Y. and Zenick, H.: Influence of parental lead exposure on subsequent learning ability of offspring, Pharmac. Biochem. Behav., 3, 561-565 (1975).

10) Driscoll, J. M. and Stegner, S. E.: Behavioral effects of chronic lead ingestion on laboratory rats, Pharmac. Biochem. Beahv., 4, 411-417 (1976).

11) Hastings, L., Cooper, G. P., Bornschein, L. and Michaelson, I. A.: Behavioral effects of low level neonatal lead exposure, Pharmac. Biochem. Behav., 7, 37-42 (1977).
12) Winneke, G., Brockhaus, A. and Baltissen, R.: Neurobehavioral and systemic effects of longterm blood lead elevation in rats, 1. Discrimination learning and open field behavior, Arch. Toxicol., 37, 247-263 (1977).

13) Overmann, S. R.: Behavioral effects of asymptomatic lead exposure during neonatal development in rats, Toxicol. Appl. Pharmacol., 41, 459-471 (1977)

14) Padich, R. and Zenick, H.: The effects of developmental and/or direct lead exposure on FR behavior in the rat, Pharmac. Biochem. Behav., 6, 371-375 (1977).

15) Shigeta, S., Misawa, T. and Aikawa, H.: Effect of lead on operant behaviour in rats, Tokai J. Exp. Clin. Med., 2, 153-161 (1977).

16) Kuribara, H., Okuizumi, K. and Tadokoro, S.: Analytical study of acquisition on free-operant avoidance response for evaluation of psychotropic drugs in rats, Jap. J. Pharmacol., 25, 541-548 (1975).

17) Pentschew, A. and Garro, F.: Lead encephalomyelopathy of the suckling rat and its implications on the porphyrinopathic nervous diseases, Acta Neuropath., 6, 266-278 (1966).

18）重田定義, 三澤哲夫, 相川浩幸, 近藤敦子：ラット のレバー押しによるSidman 型回避行動を指標とし たトルエンの毒性評価, 産業医学, 21, 68-73(1979).

（受付 1979年 3 月13日） 